\title{
Organophosphate induced delayed neuropathy: a case report
}

\author{
Organofosfata bağlı gecikmiş nöropati: Bir olgu sunumu \\ Şeniz Akçay Yalbuzdağ, Buğra İnce, Altınay Göksel Karatepe, İlker Şengül, Taciser Kaya \\ Department of Physical Medicine and Rehabilitation, İzmir Bozyaka Training and Research Hospital, İzmir, Turkey
}

Received / Geliş tarihi: October 2014 Accepted / Kabul tarihi: February 2015

\begin{abstract}
In this paper, we present the case of a 27-year-old male patient who was admitted to our clinic with bilateral drop foot and spastic paraplegia after the ingestion of organophosphate (chlorpyrifos) and diagnosed with organophosphate induced delayed neuropathy (OPIDN). Patellar deep tendon reflexes were hyperactive, Achilles reflexes were absent, and patellar clonus were present bilaterally at the neurological examination. The results of electrophysiological studies were compatible with motor axonal polyneuropathy. The patient was admitted to the neurological rehabilitation program and was able to ambulate using a pair of plastic ankle-foot orthosis and walker. Six months after the baseline, Botulinum toxin type A was injected bilaterally to adductor magnus (100 U) and adductor longus (50 U) muscles. After the Botulinum toxin injection, spasticity of the hip adductor muscles was decreased from grade 4 to grade 3 according to the modified Ashworth scale. By the end of seven-month follow-up period, partial improvement was observed in the muscle strength of the patient, and he became independent in his daily activities. In this article, we discuss possible mechanisms of OPIDN, on the basis of clinical features and the rehabilitation process of a 27-year-old male patient diagnosed with OPIDN, with a review of the current literature.
\end{abstract}

Keywords: Neuropathy; organophosphate; paraplegia.

\section{$\ddot{O} Z$}

Bu yazıda organofosfat (klorprifos) intoksikasyonundan sonra iki taraflı düşük ayak ve spastik parapleji tablosu ile kliniğimize başvuran ve organofosfat intoksikasyonuna bağlı gecikmiş nöropati (OBGN) tanısı konulan 27 yaşında bir erkek olgu sunuldu. Nörolojik muayenede patellar derin tendon refleksi hiperaktifti, Aşil refleksler yoktu ve patellar klonus iki taraflıydı. Elektrofizyolojik çalışma sonuçları motor aksonal nöropati ile uyumluydu. Hasta, nörolojik rehabilitasyon programına kabul edildi ve bir çift plastik ayak bileği-ayak ortezi ve walker ile ambulasyon yapabildi. Başlangıçtan altı ay sonra iki taraflı adduktor magnus (100 U) ve adduktor longus (50 U) kaslarına Botulinum toksin tip A enjeksiyonu yapıldı. Botulinum toksin enjeksiyonu sonrası kalça adduktörlerindeki spastisite, modifiye Ashworth skalasında derece 4'ten derece 3'e geriledi. Yedi aylık takip süreci sonunda, hastanın kas gücünde kısmi düzelme gözlemlendi ve hasta günlük yaşam aktivitelerinde bağımsız hale geldi. Olgumuzun klinik bulguları ve rehabilitasyon uygulamaları eşliğinde OBGN’nin olası mekanizmaları tartışıldı ve güncel literatür gözden geçirildi.

Anabtar sözcükler: Nöropati; organofosfat; parapleji.

Organophosphates (OP) may cause toxic effects that are classified in three stages; cholinergic syndrome, intermediate syndrome and organophosphate induced delayed neuropathy (OPIDN). ${ }^{[1]}$ Organophosphate induced delayed neuropathy is a rare neurodegenerative complication of OP ingestion. Only individual cases have been reported with OPIDN developed due to OP ingestion. The signs of OPIDN occur 7-21 days after the exposure to certain OPs. ${ }^{[1]}$ Chlorpyrifos is one of the OPs, that have been reported as a cause of
OPIDN development. ${ }^{[1-3]}$ Organophosphate induced delayed neuropathy results in the functional loss of the distal parts of sensory and motor axons of peripheral nerves, and also affects the ascending and descending tracts of the spinal cord. ${ }^{[1]}$ Gradually increased muscle tonus and motor impairment at the distal parts of the extremities are the predominant symptoms. Sensory loss may be present, but is usually less severe than motor involvement. Electrophysiological studies are compatible with motor axonal neuropathy. ${ }^{[1]}$

Corresponding author / İletişim adresi: Şeniz Akçay Yalbuzdağ, MD. İzmir Bozyaka Ĕğitim ve Araştırma Hastanesi, Fiziksel Tıp ve Rehabilitasyon Kliniği, 35170 Bozyaka, Karabağlar, İzmir, Turkey. e-mail / e-posta: senizakcay@hotmail.com 
In this report, we described a male patient who had acute organophosphates intoxication with chlorpyrifos, with the subsequent development of OPIDN, and the current literature is reviewed.

\section{CASE REPORT}

A 27-year-old-male patient presented to our tertiary outpatient clinic with the complaints of weakness in the lower limbs and an inability to walk. The medical history of patient indicated that one month before the admission to our hospital, the patient had experienced confusion, hallucinations, hypersalivation, pallor, palpitation, sweating, dyspnea, involuntary urination and defecation, muscle fasciculation and piloerection symptoms, 20 minutes after ingestion of approximately $40 \mathrm{~mL}$ chlorpyrifos with the intent to commit suicide. The patient was unconscious when admitted to the emergency department. The medical assessment revealed that he was in a coma (Glasgow Coma Score: 4, E1M2V1), blood pressure was elevated (147/91 mmHg), tachycardic (146/min) and intubated endotracheally due to absence of spontaneous breathing. He was treated with gastric lavage, activated charcoal, atropine and PAM (pralidoxime). The patient was admitted to an intensive care unit (ICU), due to the need for mechanical ventilation. Two days later the patient was fully conscious while dependence on intermittent mechanical ventilation continued for two weeks. He experienced generalized tonic clonic seizures five times and was treated with levetirasetam. By the second week, he had regained full muscle strength in all limbs and began ambulation. Between two and four weeks he described numbness in his calves, feet, hands and mouth that were resolved after four weeks, followed by weakness in lower extremities. A written informed consent was obtained from the patient.

The physical examination at the time of admission to our clinic revealed both proximal and distal weakness of the lower limbs which were graded as 3/5 and 0/5 according to Medical Research Council muscle strength grading scale, respectively. Patient had spasticity in the hip extensor and adductor muscles (grade 4), hip flexor muscles (grade 3) and knee extensor muscles (grade 3) according to modified Ashworth scale (mASH). Reflex examination showed hyperactive patellar deep tendon reflexes, and absent Achilles deep tendon reflexes bilaterally. Patellar clonus was also present bilaterally. Plantar response was not observed bilaterally. Physical examination of upper limbs was normal except mild atrophy of left hand intrinsic muscles and right Hoffmann's sign. Sensory, cerebellar and cranial nerve examinations were unremarkable.
There was no sphincter disturbance. The gait analysis exhibited a spastic gait with a stiff knee and scissoring pattern accompanied with bilateral drop foot.

Electrophysiological studies disclosed the absence of compound muscle action potential (CMAP) in distal muscles of lower limbs and diminished CMAPs in the upper limbs. Fibrillation potentials and positive sharp waves were observed in affected distal muscles of lower limbs. Sensory nerve action potentials (SNAP) were normal in all limbs. These findings were consistent with pure motor axonal neuropathy involving long axons of peripheral nervous system. Similarly, pyramidal tract lesion signs which were more distinct in the lower limbs than in the upper limbs posed long axons of central nervous system (CNS) involvement. Magnetic resonance imaging of the brain and spine were normal.

A neurological rehabilitation program consisting of neurophysiological exercises, stretching exercises and strengthening exercises was given for neuromuscular deficits. A cold pack was applied to spastic muscles. Baclofen treatment was begun with a dose of $5 \mathrm{mg}$ daily, and the dose was increased up to $40 \mathrm{mg}$ daily for medical treatment of spasticity. Botulinum toxin A was injected into the bilaterally adductor magnus (dose $100 \mathrm{U}$ ) and adductor longus (dose $50 \mathrm{U}$ ) muscles, with a total dose of $300 \mathrm{U}$ at the sixth month after the OP intoxication. One week after the botulinum toxin injection, hip adductor spasticity improved from $\mathrm{mASH}$ grade 4 to grade 3 .

At the seventh month control, motor function has improved to grade 4 of proximal and to grade 2 of distal muscle groups in the lower extremities. Compatible with these findings, low amplitude CMAPs in distal muscles of lower limbs were elicited in nerve conduction studies. Bilateral drop foot has been constant while stiff knee gait and scissoring pattern have regressed with improvement on step width. Patient was able to walk with a custommade plastic ankle-foot orthosis (PAFO) and a walker.

\section{DISCUSSION}

We described a male patient who developed OPIDN after an acute OP exposure. In our patient, muscle weakness in the lower extremities appeared four weeks after OP exposure. In addition to the distally flaccid paraplegia, upper motor neuron signs were also present. Sensorial examination was unremarkable, and electrophysiological findings confirmed pure motor axonal neuropathy. With respect to these findings, we diagnosed him with OPIDN. 
Organophosphates cause acute symptoms by the inactivation of acetylcholinesterase. This inhibition leads to an accumulation of acetylcholine in the synaptic cleft resulting in overstimulation of all acetylcholine receptors. The effects of muscarinic stimulation end up with cholinergic crisis. Overstimulation of nicotinic cholinergic receptors in sympathetic nervous system and somatic motor nerves leads to symptoms such as tachycardia, piloerection, sweating, twitching and muscle fasciculation. Response of CNS to this stimulation causes confusion, perception disturbance, seizures, convulsions and may result in coma. ${ }^{[4]}$ The second phase; intermediate syndrome occurs 24-96 hours after the OP exposure. Intermediate syndrome evaluated as a junction dysfunction due to the depolarization block characterized by prolonged overstimulation. ${ }^{[5,6]}$

After the ingestion of $\mathrm{OP}$, the progressive phase follows the latent period. ${ }^{[7]}$ Organophosphate induced delayed neuropathy is a rare neurodegenerative disorder which develops due to the loss of function of distal parts of motor and sensory axons in both peripheral nerves, and ascending, descending tracts of spinal cord..$^{[1,8]}$ Organophosphate induced delayed neuropathy differs from the other two conditions of OP exposure in that it cannot be explained by the physiological effects of acetylcholine. The main mechanism of OPIDN development is the inhibition of neuropathy target esterase (NTE) via phosphorylation. Neuropathy target esterase is an integrated membrane protein, and present in the endoplasmic reticulum of neurons. ${ }^{[9]}$ Neuropathy target esterase activity is important for axonal maintenance, because it facilitates the transport of macromolecules to the end of axons. ${ }^{[1]}$ Mutations of this protein may contribute to motor neuron diseases such as amyotrophic lateral sclerosis. Also, mutations of NTE may be a facilitating factor for OPIDN development. This hypothesis may play a role in the reason for OPIDN arising in our case even after low level exposure to chlorpyrifos. The clinical manifestations of OPIDN depend on the source of NTE. If brain NTE was inhibited, no clinical deficits appear. For OPIDN development, inhibition of peripheral nerve NTE is necessary. Inhibition of spinal cord NTE results with spastic spinal syndrome. ${ }^{[1]}$ Although the phosphorylation of NTE occurs rapidly after OP exposure, OPIDN develops after a period of about 2-3 weeks. For OPIDN development, aging of inhibited NTE enzyme was required. ${ }^{[10]}$ The reason why the 'aging' of inhibited NTE enzyme is necessary remains unclear.
Thivakaran et al. ${ }^{[7]}$ reported a 15 -year-old female who developed OPIDN following $400 \mathrm{~mL}$ chlorpyrifos ingestion similarly to our patient. Our case differs from this report with respect to a smaller dose of chlorpyrifos. In this instance, individual differences may be mentioned as heritable features which can be responsible for the development of OPIDN specified above.

The characteristic physical signs of OPIDN are high stepping gait with bilateral drop foot. Occurring spasticity, flaccid paralysis develops at the distal part of the extremities. Symptoms also may appear in upper extremities. ${ }^{[1]}$ Intrinsic muscle atrophy of the left hand was the unique sign detected in upper extremities. During the progressive phase, the symptoms of polyneuropathy are the predominant clinical manifestations. Sensorial symptoms may occur; including cramps, burning pain, numbness and tingling in the lower extremities. After the early progressive phase, the stationary phase begins with predominant clinical manifestation as paraplegia or quadriplegia. ${ }^{[5,7]}$ In our case the first symptoms of OPIDN arose four weeks after chlorpyrifos ingestion with bilateral drop foot following with intense spasticity at the proximal part of lower extremities. By the time there is regeneration of the peripheral nerve, the signs of CNS involvement may be predominant, including hyperreflexia, increased muscle tone and spastic gait. ${ }^{[1]}$ This period was called the improvement phase, in which the symptoms of CNS involvement are unmasked. ${ }^{[7]}$

Prognosis of OPIDN depends on the age of the individual (a younger age is associated with mild neuropathy), type of OP, persistence of myelopathic features, pyramidal involvement, degree of CNS involvement to peripheral nerve dysfunction. ${ }^{[1,3,7]}$ In our case, even after the seven month follow-up period, only limited functional improvement was achieved despite the intense neurological rehabilitation program and botulinum toxin injection.

In conclusion, in our patient motor strength improvement was achieved during the rehabilitation period, but CNS involvement signs still persisted at the end of seven months. He became independent with the support of assistive devices in the activities of daily living. Hip adductor spasticity improved one grade after botulinum toxin type A injection. During the rehabilitation process prescription of the appropriate assistive devices, strengthening, and stretching exercises should be applied intensively. Facilitating the functional improvement and achieving independence 
in activities of daily living should be the main aim of physiatrists. The elapsed time between $\mathrm{OP}$ exposure and development of the OPIDN may be a challenge for physiatrist. Therefore, clinicians should be aware of this rare condition to establish the diagnosis and appropriate treatment protocol.

\section{Declaration of conflicting interests}

The authors declared no conflicts of interest with respect to the authorship and/or publication of this article.

\section{Funding}

The authors received no financial support for the research and/or authorship of this article.

\section{REFERENCES}

1. Jokanović M, Kosanović M, Brkić D, Vukomanović P. Organophosphate induced delayed polyneuropathy in man: an overview. Clin Neurol Neurosurg 2011;113:7-10.

2. Jokanović M, Kosanović M. Neurotoxic effects in patients poisoned with organophosphorus pesticides. Environ Toxicol Pharmacol 2010;29:195-201.

3. Lotti M. The pathogenesis of organophosphate polyneuropathy. Crit Rev Toxicol 1991;21:465-87.

4. Jett DA. Neurotoxic pesticides and neurologic effects. Neurol Clin 2011;29:667-77.

5. Vasconcellos LF, Leite AC, Nascimento OJ. Organophosphate-induced delayed neuropathy: case report. Arq Neuropsiquiatr 2002;60:1003-7.

6. Shetye JV, Surkar SM, Karnik ND, Mehta AA. Delayed onset neuropathy along with recurrent laryngeal nerve palsy due to organophosphate poisoning and the role of physiotherapy rehabilitation. Indian J Crit Care Med 2014;18:102-4.

7. Thivakaran T, Gamage R, Gunarathne KS, Gooneratne IK. Chlorpyrifos-induced delayed myelopathy and pure motor neuropathy: a case report. Neurologist 2012;18:226-8.

8. Jokanovic $M$, Kozanovic $M$ and Stukalov PV. Organophosphate Induced Delayed Polyneuropathy. Medicinal Chemistry reviews Online 2004;1:123-31.

9. Li Y, Dinsdale D, Glynn P. Protein domains, catalytic activity, and subcellular distribution of neuropathy target esterase in Mammalian cells. J Biol Chem 2003;278:8820-5.

10. Johnson MK. The delayed neuropathy caused by some organophosphorus esters: mechanism and challenge. CRC Crit Rev Toxicol 1975;3:289-316. 